DOI: https://doi.org/10.11144/Javeriana.upsy17-5.pspm

\title{
Pedagogical Strategies to Promote Mediated Learning Experiences in Vulnerable Contexts*
}

\section{Estrategias pedagógicas favorecedoras de las experiencias de aprendizaje mediado en contextos vulnerados}

Received: 14 May 2018 | Accepted: 05 June 2018

\author{
EDUARDo SANDOVAL-OBANDo ${ }^{a}$ \\ Universidad SEK, Chile \\ ORCID: http://orcid.org/0000-0001-7471-6536 \\ Alberto Moreno DoÑA \\ Universidad de Valparaíso, Chile \\ ORCID: http://orcid.org/0000-0002-4277-0535 \\ Katherina Walper Gormáz \\ Universidad Austral de Chile, Chile \\ ORCID: http://orcid.org/0000-0003-0815-9035 \\ Diana Leguizamón Martínez \\ Pontificia Universidad Javeriana, Colombia \\ ORCID: http://orcid.org/0000-0002-0895-6192 \\ Matías Salvador Bertone \\ Universidad Maimonides, Argentina
}

a Correspondence author. E-mail:

eduardo.sandoval.o@gmail.com

How to cite: Sandoval-Obando, E., Moreno, A., Walper, K., Martínez, D., \& Bertone M. (2018). Pedagogical strategies to promote mediated learning experiences in vulnerable contexts. Universitas Psychologica, 17(5), 1-13. https://doi.org/10.11144/Ja veriana.upsy17-5.pspm

\begin{abstract}
Education is conceived as a multifaceted, multidimensional and complex process of social transformation; nevertheless, schools operate within a passive environment that restricts the learning of young people from vulnerable contexts. This qualitative study explores the pedagogical strategies of four educators from one public institution in Valdivia who work with students who have been associated with episodes of law infraction. Analytical procedures rely on content analysis following the logic of grounded theory and In-depth Interviews. From a biographical perspective, the present study identifies the pedagogical strategies of these autonomous and optimistic educators to favor the construction of modifying active environments in this vulnerable context. It also seeks to generate new lines of research on critical pedagogy in vulnerable educational contexts, strengthening and enriching the competencies of educators from Mediated Learning Experiences.
\end{abstract}

Keywords

mediated learning experiences; learning; pedagogy; adolescents law offenders.

\section{RESUMEN}

La educación se concibe como un proceso de transformación social, polifacético, multidimensional y complejo. No obstante, la escuela opera dentro de un ambiente pasivo que coarta el aprendizaje de aquellos jóvenes provenientes de contextos vulnerados. Este estudio cualitativo incluye las voces de 4 educadores pertenecientes a una institución pública en Valdivia en los que los jóvenes están asociados a episodios de 
infracción de la ley, ubicados en contextos vulnerados. En lo específico, nos basamos en el análisis de contenido siguiendo la lógica de la teoría fundamentada y las entrevistas en profundidad, desde una perspectiva biográfica para identificar las estrategias pedagógicas de los educadores autónomos y optimistas que favorecen la construcción de entornos activos modificadores. Este estudio buscó generar nuevas líneas de investigación sobre pedagogía crítica situadas en contextos educativos vulnerables, fortaleciendo y enriqueciendo las competencias de los educadores desde el punto de vista de las Experiencias de Aprendizaje Mediado.

Palabras clave

experiencias de aprendizaje mediado; aprendizaje; pedagogía; adolescentes infractores.

Educational psychology is one of the fields of study that has developed the most during the last decades, seeking to respond to the needs and complexities faced by the different actors (educators and learners, for example), within the school space and time. This critical view critiques the individualistic and fragmentary foundational pillars of psychology (Rodríguez, 2010) of the subject who learns or educates; aiming to move towards a holistic construction of knowledge that recognizes the complexity of learners' individual, familial, community, cultural and politic nature. In this perspective, we take on the challenge of favoring studies from a local and person-centered perspective, making it possible for the emergence of inter, intra or multidisciplinary work while understanding the most urgent realities and educational phenomena of the 21st century, such as educational inequality, school dropout, and marginalization. These have emerged due to a biased curriculum which is coherent with a highly stratified and technocratic economic system that has transformed schools into an inhospitable, repetitive and monotonous environment that reproduces these prevailing inequalities (Castillo, Palacios, Joignant \& Tham, 2015; Smiley \& West, 2012).

From a critical perspective, educational psychologists from non-traditional educational fields (with law offender adolescents, as is our case), we detected an excluding school practice anchored in a rigidly established and internalized curriculum, and teachers' homogenizing practices of students with regards to their educational possibilities, without acknowledging individual differences. However, and paradoxically, these practices favor socialization, making it possible to acquire knowledge that is unavoidable for students' development in daily life, providing them with tools that contribute to inclusion in a particular sociocultural group (Sandoval, 2014a). Nevertheless, is this knowledge unique and necessary for the integral development of a teenage lawbreaker? Can educators' pedagogical practices in vulnerable contexts also operate as a basis for the creation of emancipatory educational environments? How does an educator reflect on his or her professional work in vulnerable contexts? What are the educational opportunities of law-abiding adolescents who come from marginalized and socioculturally-deprived contexts?

Based on the questions raised, the present study is guided by two main purposes: a) to characterize behavioral patterns that guide teachers' professional performance working with adolescents from vulnerable contexts, and b) to describe the strategies that favor active modifying environments which will, in turn, enable pedagogical actions to reappraise teachers' professional performance, leading to the deschooling of the school.

\section{Critical Psychology as a Starting Point}

Critical psychology proposes that reality and knowledge are socially constructed (Assael \& Neumann, 1991; Fox, Prilleltensky \& Austin, 2009; Lhuilier, 2013) and critiques those practices and beliefs of study centered on a fragmented individual isolated from relational dynamics (Montero, 2004). This critical view rescues the psychology of "scientific mimicry" (Baró, 2006) that validates the thoughtless and uncritical use of theories and models produced from positivism, hedonism and the historicism of subjects. This has allowed for a clinical perspective of little educational value to prevail (Baltar, 2003). 
On the contrary, Prilleltensky and Nelson (2002) emphasize education as a space for the formation and development of "subversive" educators committed to social action and transformation. We believe that schooling complexity is characterized by diverse points of tension and reflection that take place by the accelerated historical-cultural transformations of globalization (Rodríguez, 2010, Sandoval, 2016). The need to qualitatively understand the processes, dynamics, and criteria that would favor the development of relevant pedagogical practices in vulnerable contexts is, thus, reaffirmed.

\section{The Critical Educator as a Potential Mediator of Learning in Vulnerable Contexts}

The critical educator promotes a social practice that emerges and is, recursively, nurtured by historical conditions, social and economic contexts and cultural relations that coexist within and outside schooling, conveying an ethical-political vision of reality. In this way, educators assume the task of teaching, respecting learners' knowledge and autonomy (Freire, 1998), trusting their professional capacities, generosity and active listening with regards to the educational act as a dialogic and emancipatory process.

This pedagogy invites the construction of knowledge, values and social relations that help adopt the tasks necessary to achieve critical citizenship (Giroux, 1999). It values the fact that all educational spaces and times are unique and disputed politically (McLaren \& Kincheloe, 2008). On this debate, it is the permanent critical reflection on one's professional work which allows for the generation of a path for social transformation and the construction of a more just and equitable democracy (McLaren, 2013).

The Mediated Learning Experiences in Vulnerable Contexts: Utopia or Reality? Cognitive development does not depend solely on the ability to obtain benefits from stimuli coming from the environment; it can be enhanced through mediated learning experiences - thus highlighting the importance of the educator as a potential mediator figure in its the capacity to select, organize, reorder and group the stimuli in line with specific goal (Prieto, 1989). However, school logic tends to limit the possibilities of student development: previous research has identified the diverse cognitive functions with a high educative value of adolescent offenders of law in their daily lives and has recognized how these have been disregarded by schools (Sandoval, 2012; Sandoval, 2014b). This can then be expanded far beyond immediate educational needs to develop learners' cognitive structures gradually and, in consequence, forge not only dispositions to these stimuli, but also attitudes and techniques which allow for the modification of such cognitive structures (Feuerstein, Rand, \& Rynders, 1998). Precisely, we share Moreno, Calvo and López de Maturana's (2013) view that:

The intentional attitude of the mediator to achieve student's reciprocity focuses on creating active and optimal environments for learning and on getting them involved in the task, which is why it is not a purely instrumental experience, but a co-constructed one between the teacher and the student (p. 209).

\section{Adolescents in Vulnerable Contexts: An Approach from Law-Breaking}

When referring to adolescents in vulnerable contexts, we refer to those students enrolled in the Tourism and Administration Institute (INSAT, for its acronym in Spanish) who have been linked to one or more episodes of infraction of law (judicialized or not) throughout their school career and have been, at the same time, in contact with the educators participating in the present study.

The actions proposed in Chile to deal with incidents of law-infraction committed by adolescents are relatively new: The Juvenile Criminal Responsibility Law No. 20.084 was only promulgated on June 8, 2007, by the 
Chilean Government (under the collaborative work of the National Service of Minors, The Judiciary and the Legislative Branch). It guides the juvenile justice system for young people over 14 and under 18, systematizing the processes of psychosocial intervention in the areas of accountability, reparation, empowerment and social integration (SENAME, 2007).

\section{Learning as a Process of Creating New Possible Relations}

We highlight the contributions of Vygotsky (1962, 1977), for whom learning becomes an activity of production and construction of knowledge through which the child gradually assimilates and accommodates social patterns of activity and interaction from their sociocultural environment of origin and, later in school, under conditions and activities shared with the adult in a context of permanent social collaboration. This conception of learning makes it possible to acquire language in interaction with other mental functions (thought, for example), and to integrate the various instruments created by culture. This expands learners' inherent possibilities for development and the progressive restriction of their mental functions.

In this sense, Calvo (2016) integrates the influences of Illich (1971, 1974), Feuerstein et al. (1980), Feuerstein (1983) and Freire (1998), conceiving learning as the creation of new possible relationships and diverse spaces that surpass the limits of the school institution, without necessarily having a prescriptive intention of teaching.

\section{Schooling as Spaces of Resistance and Sociocultural Straining}

Aiming at the critical view of educational processes (Baltar, 2003; Prieto, 2001), theories of resistance in education emerge as a way to build a critical psychology (Willis, 1983, 1988). These theories are based on the idea that schools are relatively autonomous institutions which not only provide spaces for teaching but also operate as a source of encounters and disagreements that sometimes make them cease to be functional for the material and ideological interests of the prevailing society; a counter-culture which integrates the political, cultural and ideological dynamics that coexist with neoliberalism (Sandoval, 2017, Vargas Monroy, Montenegro, \& Pujol, 2016). Apple (1986, 2012) and Giroux $(1997,2001)$ focus on pedagogical practice and school autonomy and its social function, perceiving classrooms as environments in which educators deploy active learning strategies, generating themes, texts, and technologies, among others, which dialogically motivate learners. In the same way, Gimeno Sacristán (2002; 2005; 2009) pursues the construction of a critical perspective of the school and curriculum as an instrument for the de-schooling of the school (Dussel, 2015; IIlich, 1971): responding to the demands of a multicultural society and respect for diversity (Torres, 2011), promoting respect, solidarity and empathy (Altarejos, Rodríguez, \& Fontrodona, 2003), and enriching pedagogical practices located in vulnerable contexts.

\section{Method}

This work is characterized by a qualitative interpretative approach as "a process of inquiry based on different methodological traditions which examine a human or social problem. Those who investigate construct a complex and holistic image, analyze words, presently detailed perspectives of informants, and conduct study in a natural situation" (Vasilachis, 2006, p. 24). We focus on the understanding of the subjects from the subjects themselves, their meanings, and their knowledge: the logical object is the multiple narratives of situations which shed light upon teachers' values, motivations and actions manifested in their behavioral patterns within the school system which includes adolescents involved in episodes of infraction of the law.

We rely on grounded theory (Strauss \& Corbin, 2002) based on content analysis of indepth interviews (Kvale, 2011) of biographical 
cut (Bolivar, Domingo \& Fernández, 2001; Goodson, 2004; Medrano, 2007). According to Bolívar, Domingo and Fernández (2001), "content analysis allows for the identification of narratives, relationship of inclusion, connections, proximity and/or causality in participant's speech" (p. 265). This makes data more manageable and facilitates codifications for interpretation.

\section{Research Design}

This work was guided by a flexible and modifiable design, interpreting the patterns of behavior displayed by educators working with adolescents in vulnerable contexts. Therefore, we assume a naturalistic character that allows us to observe the phenomenon as it occurs in its real context, from the narratives collected. This clearly reflects the non-experimental nature of our work, an aspect of research under the qualitative interpretative approach. It also corresponds to a transversal exploration, since data was collected in a time and space determined by the researchers, between January and December 2016.

\section{Research Participants}

Four educators participated in the present study: three men and one woman who will be referred to as Edgardo, Humberto, Julia, and Juan respectively, to preserve their confidentiality and identification data. The inclusion criteria of the participants ${ }^{\mathrm{i}}$ were as follows:

Educators who expressed willingness to participate voluntarily.

Educators who belong to INSAT Valdivia, which is located in a vulnerable context and in whose student have been associated with episodes of infraction of the law.

Educators who hold a degree recognized by the Ministry of Education and who have at least five years of professional experience.
Educators who reside in the commune of Valdivia (Región de Los Ríos), to facilitate contact and participation in the study.

\section{Characterization of the Educational Center}

INSAT Valdivia is an educational center of mixed character which, in the year 2016, had an enrollment number of 140 students with a school vulnerability index of $81.3 \%$. It offers professional technical education in the areas of administration and tourism. It is free of secular religious orientation and counts with 26 educators. It serves a multivariate population of students who come from vulnerable urban sectors of the commune of Valdivia -characterized as such due to parents' low educational level, low socioeconomic status, family dysfunction, unemployment, and presence of drug trafficking in the community environment with, among others).

\section{Nature of Analytical Process and Data Interpretation}

The process of analysis and interpretation of data was based on content analysis, following the logic of grounded theory (Strauss \& Corbin, 2002). This is based on the constant comparison (Flick, 2015), thematic criteria and repetition (Rodríguez, Lorenzo \& Herrera, 2005, p. 141). These constructs guided each stage of the study: from data collection to reduction and classification of information and emergent categories with the support of the software Atlas ti 6.2. In this sense, and following Bolivar, Domingo and Fernández (2001), "content analysis allows for the identification of relations of inclusion, linkage, proximity and/or causality between the narratives and interviews" ( $\mathrm{p}$. 265). Therefore, through coding data is made more manageable (through its reduction), allowing for the categorization and subsequent interpretation of these constructs. As criteria for methodological rigor, credibility, transferability, and confirmability (Guba \& Lincoln, 1985), as 
well as consistency and reciprocity have been considered (Sandín, 2003).

\section{Results}

The study unveils a set of strategies and educational techniques used by INSAT educators who encourage the construction of modifying active educational environments, expanding the experiences of mediated learning. The analysis by categories, thus, allows for the emergence of the most representative components that characterize the pedagogical behavior patterns of those educators who work in this specific vulnerable context.

The first is curricular autonomy, understood as that perception of freedom, independence, self-management and collaborative work among peers. It enables the educator to fulfill the ministerial norms and requirements satisfactorily in the various subjects they teach: Edgardo in English as a Foreign Language, Juan in Mathematics, Humberto in History and Julia in Tourism. Thus, through this autonomy, educators can develop flexible and innovative educational processes that enrich students learning (LealSoto, Dávila, \& Valdivia, 2014).

In accordance with López de Maturana (2001), we believe that it is essential to emphasize autonomy as a necessary factor to increase the flexibility of the current curriculum if the case requires. The aim is to advance the decentralization of independent and monotonous school thinking which subjugates and immobilizes the educational actors and, as a result, decentralizing the curriculum. This is observable in Humberto's interview:

I have the independence to prepare my classes, and I do so follow the guidelines given by the Ministry of Education... I have the freedom and professional respect... because if there is a situation or a professional decision that I do not want... I make it known to my superiors, and I know that they will respect me... in any other system, I would be fired immediately, even if they are not right in their opinions (Humberto, May 4, 2016, translated by the authors).
As shown, this educator acknowledges and appreciated the freedom given by the institution. In the same line, educators demonstrate a commitment to justice, equity and the emancipation of ideologies that perpetuate the status quo and education from a marketing perspective (Ball, 2006; Labaree, 2000; Múnera, 1994), increasing autonomy and self-management in teacher professionalism while also doing so in a collaborative way:

In the field of tourism, we have strengthened, during all these years, collaboration among all its members: we know each other, and we talk, assiduously, about what we can do and how to do it better together to obtain the maximum benefit of our students (Julia, May 2, 2016, translated by the authors).

Also, educators present positive motivational strategies which can be characterized as a set of didactic skills which activate learning in a fun way:

I present the contents from the simplest to the most complex, integrating different strategies: comparative tables, expanding vocabulary by identifying new words, completing sentences, etc. I believe that learning is intimately linked to games in the classroom (Edgardo, April 27, 2016, translated by the authors).

The same is present in Humberto's narrative:

In my class I integrate technology, allowing my students to listen to their own music... On other occasions, I myself sing or tell jokes, so that learning is an attractive and novel experience for them (Humberto, May 4, 2016, translated by the authors).

In this respect, López de Maturana (2001) emphasizes the importance of synergistic, noninvasive strategies that transform the school into a modifying active environment capable of amplifying the relationships between the educator, the stimulus and the student, discarding pedagogical practice which is unidirectional, authoritarian, passive, and monotonous that restricts the students' learning (Sandoval, 2014a; Sandoval, 2014b; Sandoval \& López de Maturana, 2017). Consequently, 
we identify practical elements consistent with Vaello (2011), who emphasizes the importance of educators incorporating effective strategies for group management and management within the classroom, establishing conditions conducive to learning (negotiation, motivation, control, or persuasion, for example) (p. 24).Capturing the attention of students and engaging them in their educational process in line with what the educator provides, generate more solid, independent and integral knowledge (Ortiz, 2004). Relevant experience in the Chilean context is that of Lizasoain, Ortiz de Zárate, Walper and Yilorm. (2012) who designed and adapted workshops to teach the foreign language through active methodologies. Students were required to take a leading role upon their learning process, and educators adapted to students' developing competencies by elaborating stages that tackled specific learning difficulties that arose. This need to adapt to students' learning process was also present when one educator commented on the incorporation of active methodologies as well:

I strive to incorporate active and participatory teaching methodologies, motivating the students in their learning, helping them to discover how each content will serve them. Facilitating favorable instances for collaborative and practical work, taking them to the field or using our computer lab... I like to innovate in my pedagogical work and that my classes are 100\% active. This, I assume as my responsibility (Julia, May 2, 2016, translated by the authors).

As seen in Julia's statement, the critical educator is one who takes a leading role by fostering an environment conducive to learning using collaboration among learners, as well as active methodologies that involve them and make them protagonists in their own learning process. Similar conclusions were reached by Ortiz de Zárate et al. (2014) when discussing the need for inclusion of active methodologies to foster meaningful interactions and their positive effect on students' learning processes.

All of these innovations in the classrooms, however, need to be consistent with the evaluation and assessment of the learning process. Flexible assessment strategies appear consistent with students' abilities and development, allowing educators to enhance students' self-regulation (Perrenoud, 1991):

As an educator, I understand the importance of evaluation as a tool for feedback, self-regulation and motivation for my students. Therefore, I use different types of evaluation: summative (to assess a unit), or process (to analyze the work that the student develops class to class). It seems to me that a flexible modality allows students to be more aware of their progress and/or setbacks in learning, positively strengthening the effort and commitment with which they learn (Juan, April 28, 2016, translated by the authors).

In line with these comments by INSAT educators, as well as those results obtained by Lizasoain et al. (2012) and Ortiz de Zárate et al. (2014), by strengthening the teaching methodologies and allowing for innovations in assessment processes as well, teachers advocate for better constructive alignment among the elements of the curriculum (Biggs, 1996).

As can be noted, educators' voices allow for the emergence of pedagogical intuition, that intentional, close, reciprocal and creative educational strategy that recognizes and integrates students' previous experiences with those that develop within the classroom. The above operates as a mode of pedagogical thinking that is distinct from conscious reflection, usually specifying a period of growth and internal analysis which enriches the preconscious mental process of the educator. This is especially appropriate "when it comes to uncovering hidden relationships between different areas of knowledge and understanding patterns that connect seemingly disparate experiences" (Claxton, 1999, p. 83, translated by the authors), amplifying the emergence of new meanings in the cognitive structure of the learner:

By encouraging active participation of the student, one can identify the cognitive or emotional difficulties that affect their learning. The accumulated experience allows me to 
improvise pedagogically in the development of my class, deploying the strategies most suitable and pertinent for each student... I seek to integrate the resources and personal interests of each student, as well as those that are most attractive to him (Juan, April 28, 2016, translated by the authors).

In the same way as Julia and Humberto, above, INSAT teachers make the case and confirm that acknowledging learners' prior experience and identifying their cognitive and emotional difficulties, learning and motivation are enhanced.

Another important construct that emerges from the voices of INSAT educators and the inclusion of students' knowledge and previous experiences is the promotion of practical or hands-on learning (Martínez, 2010; Sandoval, 2012), which reinforces their sense of individual competence:

I taught them that at the market, one could learn and apply English on a daily basis. To do this, I assigned special activities that favored the operational command of the language through drawings, clippings, the construction of words and phrases, and giving thanks (Edgardo, April 27,2016 , translated by the authors).

Some students knew a lot. For that reason, we started debating about that or another topic that they were confident on, seeking to relate it to their own experiences. On the other hand, with those who are more troublesome, I felt it was appropriate to capture their attention through a climate that invites to dialogue and for all to participate (Humberto, May 4, 2016, translated by the authors).

I remember having students who were fishermen; then we used their experiences by linking it to the practical learning of mathematics. For example, in calculating the sales and profits generated by their work, since that way, the young man learns to manage his resources effectively (Juan, April 28, 2016, translated by the authors).

In relation to the narratives above, educators' histories allow to distinguish social reinforcement (Abarca, Marzo \& Sala, 2002; Paula, 2000) which is characterized as rigorous, demanding and systematic pedagogic work that encourages students: to give recognition to their achievements, to acknowledge the importance of ongoing training, to persevere, and to develop the desire for self-improvement. As we stated previously: "no one persists in a task if he or she do not experience any sense of success" (Vaello, 2011).

In consequence, educators offer challenging tasks that are coherent with students' learning needs, accompanied by continuous feedback (Sheerens, 2000):

According to the advances and/or difficulties that the student shows, I offer feedback on their learning and new opportunities for development beyond the curricular requirements imposed by the system. I'm interested in them being able to move forward (Julia, May 2, 2016, translated by the authors).

As can be seen, the competencies developed within the classroom allow students to function in society, mainly due to their formation as critical subjects. Thus, we enquired after the pedagogical trajectories built by educators and analyzed how these were constructed in their narratives, recognizing the critical role they played in the formation of critical subjects (Giroux, 2001).

I trust the responsibility that I have as an educator. I believe that every student, whatever his or her opinion of us, values our work because they understand that we are the ones who give them the tools to emerge in life. I aspire to have my students take a political conscience about society... That's my job and I exercise it with great pride (Humberto, May 4, 2016, translated by the authors).

From the revision of educators' narratives, it is also possible to witness their high level of commitment towards public education, especially in acknowledging that they are dealing with adolescents from vulnerable contexts and that they have the tools to make a difference:

I have had many opportunities to change to the private education system, but I have never taken that option because I believe that my role as an educator is of great importance for the young people who attend the public system... I know 
that in this context I have real possibilities to support the educational development of those who need it most (Edgardo, April 27, 2016, translated by the authors).

In short, from INSAT educators' narratives it is possible to identify the main constructs that are the characteristic of educators who facilitate mediated learning environments. They achieve this mediated environment by means of the inclusion of active learning methodologies, innovative assessment, and collaborative work to develop learners' self-regulation skills as well as competencies acknowledging their prior experiences and making sure that they will be able to apply these in their life experiences well beyond the classroom.

\section{Discussion}

As a synthesis and about the pedagogic action that emerges from participants as a means for the revaluation of the teaching profession in nontraditional fields, we detect four critical nodes for the Educational Psychologist. In the first place, educators are aware of the low educational impact of traditional pedagogical practice, particularly in relation to young people who exhibit greater psychosocial complexity (as are lawbreakers, those that present abuse of alcohol and drugs, those in dysfunctional families, and those with repeated experiences of school failure, among others). This requires teachers to shift towards active teaching strategies in coherence with students' learning needs and interests, as well as to identify learners' relevant previous experiences with regards to topics and contents to be included in the classroom. Second, educators express rejection of school reforms implemented from the central level, since they tend to perpetuate social inequalities, often limiting the possibilities of transformation and social mobility of the most vulnerable students. Thus, they acknowledge awareness of and greatly value the autonomy they are given to implement changes in their own classrooms in accordance with their students' needs.
Thirdly, educators express a negative view towards the systems of measurement of Chilean learning (such as the standardized tests of SIMCE to measure learning, and PSU, for university selection), as they follow a fragmentary, superficial and rigid logic (Sandoval, 2017) which translates into an observed and increasing disenchantment and demotivation in both educators and learners. In other words, this is a system that turns learning into a monotonous, boring, exhausting and exclusive process, perversely flooded with economic and material incentives for those who comply with the traditional school fee. Thus, teachers aim at making a difference by contextualizing learning about students' needs and previous experiences; by allowing them the chances to apply what they learned to their own contexts and personal and professional needs. Fourth, as evidenced in their narratives, Edgardo, Humberto, Julia and Juan are optimistic and critical professional educators as they value the environment they work at, respect students and acknowledge individual differences, and make sure that equal opportunities are provided to function in society.

Providing a link from within the field, we need to acknowledge that these results agree with those found by Hattie (2015) who developed a method to classify the elements that influenced learning and achievement, and their effect in size, through different meta-analyses. In his innovative study "Visible Learning" he classified 138 influences that are related to learning outcomes: from very positive effects to very negative effects. Teacher's achievement estimate was the variable analyzed with the most significant effect size.

Educators' valuable contributions show a dialogic relationship with their students, promoting greater capacity for learning from their mistakes and the importance of respect and affectivity in every educational act. Thar way teachers are successfully sowing the germ for the de-schooling of the school and modifying environments that contribute to the emotional and cognitive development of every educated subject by means of correct mediation. 
Finally, it is necessary to acknowledge one of this study's limitations as well as its main implication. Little research has been done in the national and local context which incorporates the contributions of educational psychology and which also focuses on pedagogical practices that ensure mediated learning in vulnerable contexts from a critical perspective. During the analytical process, data reached a complex volume of information that made it challenging to reach theoretical saturation through constant comparison and data reduction of participants' narratives.However, emergent categories were found and the main objective was reached with regards to identifying pedagogical strategies that characterize mediated learning environments. This study's main implication relies on the fact that it sought to generate new lines of research on critical pedagogy situated in vulnerable educational contexts, strengthening and enriching the competencies of educators from the perspective of mediated learning experiences and educational psychology. In the same manner, it is possible to assert that the present study succeeds in giving voice to those educators who make a difference in these vulnerable environments in which marginality and social exclusion have become the norm.

\section{Acknowledgements}

These reflections are part of the doctoral thesis developed by the principal author entitled "The Teacher as an Emotional and Cognitive Mediator of Young people in vulnerable contexts: Tensions and challenges for the Transformation of pedagogical practice." Work funded by the Advanced Human Capital Program - National Ph.D. Scholarship 2013, CONICYT.

\section{References}

Abarca, M., Marzo, L., \& Sala, J. (2002). La educación emocional y la interacción profesor/a-alumno/a. Revista Electrónica Interuniversitaria de Formación del Profesorado, 5(3), 1-4. Retrieved from http://aufop.com/aufop/revistas/arta/d igital/108/802

Altarejos, F., Rodríguez, A., \& Fontrodona, J. (2003). Retos educativos de la globalización. Hacia una sociedad solidaria. Barañáin: Universidad de Navarra.

Apple, M. (1986). Ideología y currículo. Madrid: Akal.

Apple, M. (2012). Can education change society? New York: Routledge.

Assael, J. \& Neumann, E. (1991). Clima emocional en el aula. Un estudio etnográfico de las prácticas pedagógicas. Santiago de Chile: P.I.I.E.

Ball, S. (2006). Education policy and social class. The selected works of Stephen J. Ball. London: Routledge.

Baltar, M. (2003). El sentido del diagnóstico psicológico escolar. Un análisis crítico y una propuesta en construcción. Psicoperspectivas, 2(1), 7-34. Retrieved from http://www.psicoperspectivas.cl/index .php/psicoperspectivas/article/viewFile/1/1

Biggs, J. (1996). Enhancing teaching through constructive alignment. Higher Education,32 (3), 347-364. https://doi.org/1 $0.1007 / \mathrm{BF} 00138871$

Bolívar, A., Domingo, J., \& Fernández, M. (2001). La investigación biográfico narrativa en educación. Enfoque y metodología. Madrid: La Muralla.

Calvo, C. (2016). Del mapa escolar al territorio educativo. diseñando la escuela desde la educación (6th ed.). La Serena: Nueva Mirada.

Castillo, J., Palacios, D., Joignant, A., \& Tham, M. (2015). Inequality, distributive justice and political participation: An analysis of the case of chile. Bulletin of Latin American Research, 34(4), 486-502. https://doi.org/10 $.1111 /$ blar. 12369

Claxton, G. (1999). Cerebro de liebre, mente de tortuga. Barcelona: Urano.

Dussel, E. (2015). Filosofías del sur. Descolonización y transmodernidad. Madrid: Akal. 
Feuerstein, R. (1983). La teoría de la modificabilidad estructural cognitiva. Zaragoza: Mira S.A.

Feuerstein, R., Rand, Y., \& Rynders, J. (1998). Don\#t accept me as I am. Helping Retarded people to excel. New York: Plenum Press.

Feuerstein, R., Rand, Y., Hoffmann, M. \& Miller, R. (1980). Instrumental enrichment: An intervention program for cognitive modifiability. Baltimore: Park Press University.

Flick, U. (2015). El diseño de investigación cualitativa. Madrid: Morata.

Fox, D., Prilleltensky, I., \& Austin, S. (Eds.) (2009). Critical psychology: An introduction (2nd ed.). Londres: Sage.

Freire, P. (1998). Pedagogía de la autonomía. México: Siglo XXI.

Gimeno Sacristán, J. (2009). La pedagogía por objetivos: Obsesión por la eficiencia. Madrid: Morata.

Gimeno Sacristán, J. (2005). El alumno como invención. Madrid: Morata

Gimeno Sacristán, J. (2002). Educar y convivir en la cultura global. Madrid: Morata.

Giroux, H. (2001). Los profesores como intelectuales perfomativos. Docencia, 15, 60-65. Retrieved from http://www.academia.edu/31316376/ GIROUX_Henry_Los_profesores_como_i ntelectuales transformativos

Giroux, H. (19999). Pedagogía crítica como proyecto de profecía ejemplar: Cultura y política en el nuevo milenio. In F. Imbernón (Coord). La educación en el siglo XXI. Los retos del futuro inmediato, (pp. 23- 37). Barcelona: GRAO.

Giroux, H. (1997). Teoría y resistencia en educación (3rd Ed.). México: Siglo XXI.

Goodson, I. (2004). Historias de vida del profesorado. Barcelona: Octaedro.

Guba, E., \& Lincoln, Y. (1985). Naturalistic inquiry. London: Sage.

Hattie, J. (2015). The applicability of visible learning to higher education. In Scholarship of Teaching and Learning in Psychology, 1(1), 79-91. http://dx.doi.org/10.1037/st1000002 1
Illich, I. (1971). La sociedad desescolarizada. Barcelona: Barral.

Illich, I. (1974). Alternativas. Ciudad de México: Planeta.

Kvale, S. (2011). Las entrevistas en investigación cualitativa. Madrid: Morata.

Labaree, D. (2000). On the nature of teaching and teacher education. Difficult practices that look easy. Journal of Teacher Education, 51(3), 228-233. Retrieved from https://web.stanford.edu/ dlabaree/p ublications/Nature_of_Teaching_and_TE. pdf

Leal-Soto, F., Dávila, J., \& Valdivia, Y. (2014). Bienestar psicológico y prácticas docentes con efectos motivacionales orientadas al aprendizaje. Universitas Psychologica, 13(3), 15-23. http://dx.doi.org/10.11144/Javerian a.UPSY13-3.bppd

Lhuilier, D. (2013). El trabajo como instrumento de resistencia a la opresión carcelaria. Universitas Psychologica, 12(4), 1011-1024. http://dx.doi.org/10.11144/Jav eriana.UPSY12-4.tcir

Lizasoain, A., Ortiz de Zárate, A., Walper, K., \& Yilorm, Y. (2012). Estudio descriptivo y exploratorio de un taller de introducción a las técnicas teatrales para la enseñanza/aprendizaje de una lengua extranjera. Estudios Pedagógicos, 38(2), 157-167. http://dx.doi.org/10.4067/S071807052012000200010

López de Maturana, S. (2001). Los niños y la escolarización. Ambientes activo modificantes que propician la descentralización del pensamiento del educador. In Congreso Europeo: Aprender a Ser, Aprender a Vivir Juntos. Asociación Mundial de Educadores Infantiles: Santiago de Compostela. Recuperado de: http://ww w.waece.org/biblioteca/pdfs/d202.pdf

Martín Baró, I. (2006). Hacia una psicología de la liberación. Revista Electrónica de Intervención Psicosocial y Psicología Comunitaria, 1(2), 7-14. Retrieved from http://www.facso.uchile.cl/psicologia/ epe/_documentos/getep/martin_baro_psic ologia_liberacion.pdf. 
Martínez, M. (2010). Aprendizaje servicio y responsabilidad social de las universidades. Barcelona: Octaedro.

McLaren, P. (2013). A critical patriotism for urban schooling: A call for a pedagogy against fear and denial and for democracy. Texas Education Review, 1, 234-253. Retrieved from: http://txedrev.org/wp-content/uploa ds/2013/11/McLaren_A-Critical-Patriotis mfor-Urban-Schooling_TxEdRev.pdf

McLaren, P., \& Kincheloe, J. (Eds.) (2008). Pedagogía crítica: De qué hablamos, dónde estamos. Barcelona: GRAÓ.

Medrano, C. (2007). Las historias de vida. Implicaciones educativas (Coord.). Buenos Aires: Alfagrama.

Montero, M. (2004). Relaciones entre psicología social comunitaria, psicología crítica y psicología de la liberación: Una respuesta latinoamericana. Psyche, 13(2), 17-28. http://dx.doi.org/10.4067/S0718-22 2820040002000171

Moreno, A., Calvo, C., \& López de Maturana, S. (2013). Aprender en y desde la motricidad humana: Educación, escuela y mediación pedagógica. Revista Iberoamericana de Educación, 62, 203-216. Retrieved from https://rieoei.org/historico/ documentos/rie62a11.pdf

Morse, J. (2005). Asuntos críticos en los métodos de investigación cualitativa. Alicante: Universidad de Alicante.

Múnera, L. (1994). Las dimensiones del Estado. In Constitución Política y reorganización del Estado. Bogotá: Universidad Nacional de Colombia.

Ortiz, A. (2004). Aprendizaje desarrollador: Una estrategia pedagógica para educar instruyendo. Barranquilla: Antillas.

Ortiz de Za\#rate, A., Walper, K., Aros, P., Hidalgo, D., Siebert, F., \& Rojas, J. (2014). El papel de la interaccio\#n significativa y las te\#cnicas drama\#ticas en la educacio\#n de estudiantes con discapacidad visual en la UACh. Colombian Applied Linguistics Journal, 16(2),
261-276. https://doi.org/10.14483/udistrita 1.jour.calj.2014.2.a08

Paula, I. (2000). Habilidades sociales: Educar hacia la autorregulación. Barcelona: Horsori.

Prilleltensky, I., \& Nelson, G. (2002). Doing psychology critically: Mailing a difference in diverse settings. New York, NY: Palgrave Macmillan

Perrenoud, Ph. (1991). Pour une approche pragmatique de I'évaluation formative. Mesure et évaluation en education, 13(4), 49-81. Retrieved from https://www.unige.ch/fapse/SSE/teac hers/perrenoud/php_main/php_1991/1991 12.html

Prieto, M. (2001). La investigación en el aula: ¿Una tarea posible? Valparaíso: Universidad Católica de Valparaíso/Ministerio de Educación. Programa de Fortalecimiento de la Formación Inicial de Docentes, Ediciones Universitarias de Valparaíso.

Prieto, M. (1989). Modificabilidad cognitiva y P.E.I. Madrid: Bruño.

Rodríguez, W. (2010). Hacia una psicología social crítica de la educación en América Latina. Paideia, 5(1), 1-14. Retrieved from http://paideia.uprrp.edu/wp-content/ uploads/2013/11/Hacia-una-psicolog\%C3

\%ADa-social-cr\%C3\%ADtica-de-la-educa ci\%C3\%B3n-en-America-Latina.pdf

Rodríguez, C., Lorenzo, O., \& Herrera, L. (2005). Teoría y práctica del análisis de datos cualitativos. Proceso general y criterios de calidad. Revista Internacional de Ciencias Sociales y Humanidades, 15(2), 133-154. Retrieved from http://www.redalyc.org/pdf/ 654/65415209.pdf

Sandín, M. (2003). Investigación cualitativa en educación, fundamentos y tradiciones. Madrid: Mcgraw-Hill.

Sandoval, E., \& López de Maturana, S. (2017). Desafíos Educativos en torno a las experiencias de aprendizaje mediado con adolescentes infractores de ley. Profesorado, Revista del Currículum y Formación del Profesorado, 21(2), 377-391. https://recyt.fecyt.es/index.php/pr ofesorado/article/view/59465 
Sandoval, E. (2017). El docente como mediador emocional y cognitivo de jóvenes en contextos vulnerados: Tensiones y desafíos para la transformación de la práctica pedagógica (Tesis de Doctorado en Ciencias Humanas). Facultad de Filosofía y Humanidades, Universidad Austral de Chile, Chile.

Sandoval, E. (2016). Cruzando las fronteras de la pedagogía crítica en el trabajo con adolescentes infractores de ley. Revista de Pedagogía, 37(101), 175-191. Retrieved from http://eduardosandoval.cl/2016/12/30 /publicacion-articulo-cruzando-las-fronter as-de-la-pedagogia-critica-en-el-trabajo-co n-adolescentes-infractores-de-ley/

Sandoval, E. (2014a). Posibilidades educativas del adolescente infractor de la ley: desafíos y proyecciones a partir de su propensión a aprender. Psicología Educativa, 20(1), 39-46. https://doi.org/10.1016/j.pse.2014.05.005

Sandoval, E. (2014b). Propensión a Aprender de los Adolescentes Infractores de Ley: Reflexiones desde el Enfoque Biográfico. Polis, 13(37), 251-273. Retrieved from http s://journals.openedition.org/polis/9829

Sandoval, E. (2012). Construcción Socio-histórica de la Propensión a Aprender de los Adolescentes Infractores de Ley. (Tesis de Magíster en Educación, Mención Políticas y Gestión Educativa). Facultad de Filosofía y Humanidades, Universidad Austral de Chile, Chile. Recuperado de http://cybertesis.uach.cl/tesis/uach/2012 /egs218c/doc/egs218c.pdf

Sheerens, J. (2000). Improving school effectiveness. Paris: International Institute for Educational Planning \& UNESCO.

Smiley, T., \& West, C. (2012). The rich and the rest of us: A poverty manifesto. New York: SmileyBooks.

Strauss, A., \& Corbin, J. (2002). Bases de la investigación cualitativa. Técnicas y procedimientos para desarrollar la eoría fundamentada. Antioquia: Universidad de Antioquia.

Torres, J. (2011). La justicia curricular. El caballo de Troya de la cultura escolar. Madrid: Morata.
Vaello, J. (2011). Cómo dar clase a los que no quieren. Barcelona: Graó.

Vargas-Monroy, L., Montenegro, M., \& Pujol, J. (2016). Miradas, formas de hacer y relaciones en la constitución de una investigación crítica. Universitas Psychologica, 14(5), 1833-1851. Retrieved from http://revistas.javeriana.edu.co/index. php/revPsycho/article/view/15610

Vasilachis, I. (Coord) (2006). Estrategias de investigación cualitativa. Barcelona: Gedisa.

Vygotsky, L. (1977). Development of higher psychological functions. Soviet Psychology, 15(3), 60-73. https://doi.org/10.2753/RPO $1061-0405150360$

Vygotsky, L. (1962). Thought and language. Cambridge: Met Press.

Willis, P. (1988). Aprendiendo a trabajar. Cómo los chicos de clase obrera consiguen trabajos de clase obrera. Madrid: Akal.

Willis, P. (1983). Cultural production and theories of reproduction. In L. Barton y S. Walker (Eds.), Race, class and education (pp. 109-138). Beckenham: Croom Helm.

\section{Notes}

i This study follows ethical criteria required for its rigorous development: informed consent was granted by all participants: the regional head of education dept., school Director, teachers and students (Morse, 2005; Sandín, 2003).

* Research article. 